\title{
30 år med Orientalism
}

Med dette nummer af Dansk Sociologi ønsker vi at markere, at Edward W. Saids moderne klassiker Orientalism - Western Conceptions of the Orient har passeret sit 30 års jubilæum. Bogen var ved sin udgivelse i 1978 relativt ubemærket. Sidenhen er den imidlertid blevet et toneangivende værk i brede social- og humanvidenskabelige sammenhænge, hvilket fremgår af de mange sprog, værket er blevet oversat til, herunder dansk i 2002, og genudgivelser, hvor Said i nye efterord (1995) og forord (2003) forholder sig til nogle af reaktionerne på Orientalism. Bogen udkom i kølvandet på de arabiske-israelske krige i 1967 og 1973, oliekrise og venstreorienteret, intellektuel kritik af Vestens politik i forhold til den tredje verden, og den udgjorde på den måde en agiteret kritik af vestlige forfatteres koloniale og imperiale attitude til araberne. Samtidigt hævdede Said også en analytisk legitimitet, fordi han baserede sit arbejde på Michel Foucaults begreb om diskurs, og dermed erklærede han med bogen at dokumentere en vestlig diskurs om Orienten, som fastholdt denne og dens mennesker i en underlegen position i forhold til Vesten. Orientalism var således et de centrale værker i 1970erne, som udbredte en populariseret "diskursanalyse", der stadig gør sig gældende i dag.

\section{Vestlige forestillinger om Orienten \\ - deres karakter og funktion ifølge Said}

Som det fremgår af selve titlen til Saids klassiker, skal de "vestlige forestillinger om Orienten" ses i lyset af det fænomen, han betegner som "orientalisme". Tidligere har denne term enten betegnet en bestemt akademisk disciplin, som havde Orienten som sit genstandsfelt - i dansk sprogbrug tales der i den sammenhæng gerne om orientalistikken - eller til retninger inden for vestlig malerkunst, musik og litteratur, som var inspireret af Orientens æstetik eller filosofi. Hos Said refererer orientalisme derimod til en distinkt tankefigur eller diskurs, der skulle have formet måden, hvorpå man i Vesten har tænkt og forestillet sig Mellemøsten på. Selvom beskrivelser af Mellemøsten på et substantielt plan kan variere meget, er de ifølge Said alle formet af den samme orientalistiske tankefigur kendetegnet ved en ontologisk, epistemologisk og normativ distinktion mellem en Orient - eller Mellemøsten - og en Occident - eller Vesten - der fremstilles som hinandens modsætninger og dette altid i sidstnævntes favør. Et eksempel kunne være fremstillingen af "den orientalske kvinde", der på det substantielle plan har forandret sig over tid fra den orientalistiske malerkunsts sanselige og kropslige væsener til i dag at være omvandrende chadors. Det overordnede skema skulle dog være vedblevet med at være det samme. Orientaleren forbliver med at blive fremstillet som ufri i modsætning til sin vestlige søster først i form af Victoria-tidens 
kyske kvinde, der i kontrast til sin orientalske søster, ikke er i lysternes vold, og siden i form af den æggende Spice-Girl, der er frigjort og har et naturligt forhold til sin krop i modsætning til den kønsforskrækkede og formummede orientaler.

Når man i en europæisk eller amerikansk sammenhæng har forholdt sig til mellemøstlige forhold, skulle denne orientalske tankefigur således have fungeret som et slags filter, hvor nogle aspekter ved regionen er blevet henholdsvis be- og nedtonet, for at Mellemøsten kunne fremstå i overensstemmelse med den i tankefiguren indlejrede aprioriske antagelse om, at Mellemøsten nærmest udgør Vestens absolutte modsætning. Med andre ord er det orientalske Mellemøsten så at sige blevet orientaliseret gennem Vestens repræsentationer, der således er med til at konstruere, hvad de foregiver blot at repræsentere, og det er i det lys, at Said bemærker, at Orienten ikke blot er en kendsgerning, men menneskeskabt.

Selvom de vestlige repræsentationer af Mellemøsten af den grund skulle være mere lydhøre for den kultur, som de er skabt i, end deres formodede genstand og således skulle have "mindre at gøre med Orienten end med "vores" verden", bør dette ifølge Said hverken forlede os til at tro, at orientalismen er et uskyldigt eller virkningsløst foretagende. Den europæiske og amerikanske selvforståelse såvel som måde at udøve magt på skulle derimod være tæt sammenvævet med forestillingen om et orientalsk og fremmedartet Mellemøsten. Hvad førstnævnte angår, skulle et orientaliseret Mellemøsten have fungeret som det konstituerende modbillede for en europæisk, respektive amerikansk selvopfattelse som del af en occidentalsk, altså vestlig, kultur, hvis antagede demokratiske, rationelle og oplyste karakter er blevet kontrasteret med beskrivelser af en despotisk, irrationel og barbarisk Orient. Mellemøsten har - som det erklæres i Orientalism - "været med til at definere Europa (eller Vesten)", ligesom "den europæiske kultur øgede sin styrke og identitet ved at se sig selv i modsætning til Orienten, der blev en slags erstatning for jeget eller ligefrem et undergrundsjeg". Ud over denne identitetskonstituerende funktion peger Said med inspiration fra Foucaults overvejelser om forholdet mellem magt og viden på, hvordan denne orientalisering af Mellemøsten ydermere skulle have fungeret som en integreret del af en "vestlig metode til at dominere, omstrukturere og få magt over Orienten".

Det er ikke mindst i relation til denne sidstnævnte funktion, at orientalistikken bringes ind i billedet. Selvom orientalisme for Said som sagt ikke kan reduceres til denne specifikke akademiske disciplin, spiller den ikke desto mindre en central rolle for hans analyse. Orientalistikken skulle således udgøre et af de centrale felter for produktionen af denne indflydelsesrige orientalistiske tankefigur, og det er ifølge Said ingenlunde noget tilfælde, at den vokser frem som en selvstændig disciplin samtidigt med, at det europæiske engagement i Mellemøsten for alvor blev indledt. Der skulle således eksistere en intim forbindelse mellem den europæiske kolonialisme og orientalister- 
ne, hvis tilsyneladende nøgterne og videnskabelige repræsentationer af de mellemøstlige samfund som passive, tilbagestående, underlegne og dermed kolonialiserbare i første omgang skulle have banet vejen for deres faktiske kolonialisering og siden medvirket til at legitimere selv samme. Dette tætte, men som oftest tilslørede forhold mellem akademisk viden og magt skulle endvidere ikke være reserveret til en fjern kolonial fortid. I forordet til 25års jubilæumsudgaven af Orientalism fremsatte Said således en bandbule mod mellemøstforskere som Bernard Lewis og Fuad Ajami, som ved at genfremsætte klassiske orientalistiske dogmer efter hans mening havde været med til at bane vejen for den amerikanske invasion af Irak i 2003.

\section{Edward W. Said, thirdworldism og postkolonialisme}

Egentligt handler Orientalism om vestlige forskere og forfatteres beskrivelser af Orienten og araberne. Når den alligevel har haft stor betydning i mange andre social- og humanvidenskabelige felter skyldes det både, som mange kritikere har påpeget, intellektuel mode men også, at Said fremhæver et grundforhold, som gør sig gældende i social- og humanvidenskaben: nemlig repræsentationsproblematikken. Hvordan beskriver man "andre" uden at gøre dem til et billede? Saids værk kom til at fremstå som en af de bøger, man kan henvise til for at erklære, at man tager den problemstilling alvorligt. Desuden fremhævede Said i Orientalism magtforholdet mellem "de beskrivende" og "de beskrevne". Orientalistikken blev anklaget for at tjene kolonialismens og imperialismens interesser ved at beskrive Orienten og orientalerne som objekter, der kunne manipuleres og regeres, som var de en del af et kultiverbart landskab. Uden for orientalistikken er Saids eksempel på dette magtforhold blevet et ikon for den abstrakte koloniale magt, som beskriver sine undersåtter med henblik på kontrol.

Edward W. Said blev omkring 1970 engageret i palæstinensernes kamp mod Israel og for et palæstinensisk hjemland. Den primære anledning var krigen i 1967, som var en politisk formativ begivenhed for mange andre intellektuelle også på linje med Vietnamkrigen og andre konflikter i efterdønningerne af kolonialismen. Saids palæstinensiske baggrund medvirkede i løbet af 1970erne til at profilere ham som en palæstinensisk intellektuel i eksil i New York samtidigt med, at udviklingen i Mellemøsten efterhånden skabte et behov for et "palæstinensisk synspunkt". Said befandt sig mestendels på kanten af den officielle palæstinensiske nationalisme, som han havde et ambivalent forhold til, selvom han ofte af kritikere er blevet udlagt som palæstinensernes chefideolog eller "terrorprofessor". Trods sin uforbeholdne sympati for palæstinensernes sag var Saids primære intellektuelle bidrag at forny og revitalisere en mere generel thirdworldism, som spillede en ideologisk og teoretisk væsentlig rolle i den venstreorienterede intellektualisme fra slutningen af 1960erne og frem. Thirdworldism eller rettere i udgangspunktet tiermondisme kom ud af afkoloniseringen efter Anden Verdenskrig, Algeriet- 
krigen 1954-1962 med filosofisk inspiration i eksistentialisme, marxisme og psykoanalyse og var primært fransksproget med forfattere som Aimé Cesaire, Frantz Fanon, Albert Memmi og Jean-Paul Sartre i 1950erne og 60erne. Meget kort udlagt var tiermondismens fokus på kolonialismens overdetermination af den koloniseredes psyke, personlighed og værdisystemer som en signifikant konsekvens af den koloniale udbytning. Man kan sige, at tiermondismen interesserede sig for kolonialismens kulturelle og psykologiske superstruktur. Det udviklede sig i slutningen af 1960erne og i 1970erne med Israel-Palæstina konflikten og Vietnamkrigen til den primært engelsksprogede thirdworldism, som blev et centralt aspekt af både demokratiske og revolutionære venstreorienteredes ideologiske og teoretiske anskuelser.

Said blev i løbet af 1970erne prominent som en af de "hybride" intellektuelle, som både var hjemme i Vestens akademia og alligevel kunne hævde en særlig indsigt i de undertryktes perspektiv gennem sin etnicitet. Sammen med bl.a. Gayatri Spivak og Homi K. Bhabha blev han en central figur for postkolonialismen, som udspringer af denne optagethed af kolonialismens kulturelle effekter. Da Orientalism udkom i 1978 var den brede mere folkelige interesse for den tredje verdens frigørende potentiale ved at ebbe ud i både USA og Europa, men den amerikanske mellemøstforsker Martin Kramer har nok ret $i$, at det ikke var tilfældet i akademia, hvor dem, der var studerende i 60erne og starten af 70erne, blev fastansatte i slutningen af 1970erne og i 1980erne. Saids popularitet og den brede læsning af Orientalism på universiteterne fulgte utvivlsomt med en bølge af kampusradikalisme, som var meget kritisk over for især amerikansk og israelsk udenrigspolitik, men også over for de borgerlige, kapitalistiske samfund som sådan. Med Saids bog blev der tilbudt en kulturel forklaring på Vestens kontinuerlige undertrykkelse af "de andre", som kunne afløse tidligere tiders eksplicit marxistiske og psykoanalytiske perspektiver. På den måde var Said med til at forbinde det kampusradikale perspektiv med udviklinger inden for historiefaget som New Cultural History, kultursociologi, antropologi og postkoloniale perspektiver inden for studiet af international politik. Disse udviklinger kan samles i begrebet "kultur" som mere eller mindre dominerende forklaringsmatrix for menneskets væren og handlen eller som forklaringsmatrix for det, vi ikke kan forstå.

Orientalism er en polemisk bog, og den har siden 1980erne været centrum for en kontinuerlig skyttegravskrig, som har varieret $\mathrm{i}$ intensitet. Intentionen for redaktørerne af dette nummer er ikke at vælge side for eller imod Orientalism, men at vurdere værkets betydning inden for en række felter såsom dansk indvandrerforskning, islamforskning, mellemøststudier, antropologi og jødiske kulturstudier. Således er intentionen ikke at deltage i hverken helgenkåring eller nedrakning af Said, men derimod både at kritisere og påskønne værkets effekter i social- og humanvidenskab. I den forbindelse er det relevant at pege på værkets forskellige effekter i forskellige akademiske og geografiske kontekster. Dette nummer viser eksempelvis, at Orientalism's 
betydning paradoksalt har været relativt beskeden i mellemøststudier, men derimod markant i jødiske kulturstudier ligesom der inden for samme akademiske felter er forskelle i påvirkningen fra Saids værk i en europæisk og amerikansk kontekst. Receptionen af værket kan ikke reduceres til blind efterfølgelse af Saids perspektiver, men kan heller ikke siges at være uafhængig af den kritik, som Said rettede mod vestlig social- og humanvidenskab. I kontekst af markante globale migrationsbølger, fornyet multikulturalismedebat, en vedvarende Israel-Palæstina konflikt, islamisk terror og ikke mindst fornyet vestlig intervention i Mellemøsten synes en markering af Orientalism's 30 års jubilæum yderst relevant.

Manni Crone, Jakob Egholm Feldt og Morten Valbjørn 